Indonesian Journal of Social Sciences Volume 13 No. 01, January-June 2021, page 11-20

\title{
The influence of excessive use of social media
}

\author{
Ariella Christ Maharani \\ Department of Anthropology \\ Faculty of Social and Political Sciences, Universitas Airlangga, Surabaya \\ Address: Jalan Airlangga 4-6 Surabaya, Indonesia \\ E-mail: ariellachrist13@gmail.com
}

\begin{abstract}
Technology that is overgrowing makes the audience increasingly spoiled with the existing features, including social media, which is a part of today's technological advances. Many platforms offer features that make users even more interested in sharing their excellent routines on these platforms. However, excessive use of social media and poor use harms users. One of the problems that result from overuse and poor use is the increasing incidence of depression. Individuals who experience depression tend to feel insufficient, and a feeling of wanting to end their life arises. Hence, it is necessary to know the causes and solutions to reduce the impact of excessive use of social media. This research method is quantitative. Researchers shared questionnaires to 101 respondents who were social media users aged at least 15 years. The results of this study indicate that most respondents tend to experience mood changes when using social media. That can occur because of jealousy when seeing content on their social media. Therefore, social media users must control their use of social media, for example, by being optimistic, doing fun activities, and increasing their religiosity.
\end{abstract}

Keywords: depression; technology; education; social media; psychology

Article History

Received: April 13, $2021 \quad$ Accepted: June 8, 2021

Cite this as: Maharani AC (2021) The influence of excessive use of social media. Indonesian Journal of Social Sciences 13 (1):11-20. DOI 10.20473/ijss.v13i1.26351.

\section{Introduction}

From year to year, technology began to develop rapidly. Scientists are competing to find new technology-based innovations to make it easier for humans to live their lives. The more sophisticated the technology that is now, the more people of all ages and genders can enjoy the convenience of finding whatever information they need-one of the current technological developments in social media (Setiawan 2018; Husaini 2018). Social media has become the platform label for digital technology that is currently developing. It makes it easier for people worldwide to communicate in the photo or video media (Sabbah et al. 2019). Social media also helps users to communicate and meet people who are far from them smoothly. The technology that shade it all is social media.

According to Putri et al. (2016), social media is online media that makes it easy for users to participate, share, and create something. According to Mahdia (2018), social media is a digital communication channel for sharing photos and videos, and users can share them with the public. According to Vaterlaus et al. (2015) in Karmila (2020), based on research results, $80 \%$ of respondents aged 18-29 years using social media to share photos online, so this photo-sharing feature is popular. Examples of social media that many teenagers have are Twitter, Facebook, and Instagram. In simple terms, social media becomes an association where individuals can freely express something they are feeling and also carry out social interactions without being face to face directly (Kaplan \& Haenlein 2010). It looks pretty pleasing to the individuals who see it because they can get the information they want to know from individuals they consider to be good examples of physicality, wealth, education, or even happiness. Without realizing it, individuals who continue to see other people's lifestyles on 
social media without knowing the truth create new assumptions that cause them to be unhappy and compare with other people they see more than themselves. This thinking makes the individual feel that he always lacks and also feels unworthy of what he labels as an example. That is the cause of mental health problems, one of which is depression.

Depression is an individual problem in controlling their feelings and thoughts. Depression is a mental health problem for a person, and it requires special attention from the surrounding environment and the experts (Dine 2010). Depression can appear regardless of age and gender. This mental disorder makes sufferers feel sad for a long time, lose motivation to live, and in more severe cases, lead to suicide (Davison \& Neale 2003).

Social media has become a significant role taker in increasing depression in the world. According to Retnowati (2015) in Pratiwi \& Pritanova (2017), the number of social media users in Indonesia is primarily teenagers. The positive use of social media can increase achievement, but use in a negative direction will negatively impact adolescents. One example is the case related to humiliation and bullying that can trigger depression. The Indonesian Ministry of Health in 2019 stated that nearly 12 million children over 15 years of age experienced depression, and from the 2016 data, nearly 1800 cases of suicide due to depression were recorded. This incident cannot be ignored. The government and society itself must create a conducive social media environment so that people who use social media can get inspiration, not become depressed and depressed. Research conducted by Sarah Jensen (2018) in Yolanda (2019) on the impact of social media shows that $51 \%$ of people who use social media in America experience feelings of loneliness and depression. These young social media users feel lonely because they tend to have the desire to appear with the perfect life.

Based on this background, researchers are interested and want to know about the ease with which individuals experience depression due to social media, the symptoms of depression they experience, and the right solutions to deal with depression caused by social media. Based on this, this study aims to see the extent to which depression attacks adolescents and young adults due to social media use. Besides, this study can also identify common symptoms that occur in current depression sufferers and find appropriate solutions in treating depression caused by social media.

\section{Methods}

This study uses a quantitative method. Researchers used data collection techniques in the form of a questionnaire from Google Form. This questionnaire contains questions about the state of respondents who use social media. This study focuses on the possible symptoms of depression due to social media for adolescents and young adults. Adolescents and young adults are the most significant users of social media. The sampling technique in this study was purposive sampling, which is a technique that determines the sample with specific considerations (Sugiyono 2016). In this study, researchers distributed questionnaires to social media users, and users must have a minimum age of 15 years. Respondents in this study were 101 social media users. Researchers used descriptive statistical data analysis. According to Sugiyono (2016), descriptive statistics can analyze data by describing it based on current results.

\section{Results and Discussion}

Changes in mood that are significant and occur continuously will make the sufferer less excited, withdraw from social interactions, and have trouble sleeping. That is at risk of becoming a depressive disorder (Ninaprilia 2015). Depression is a change in mood that becomes very bad, characterized by a feeling of hopelessness, gloom, and feeling useless in the individual's life. These feelings can lead to depression and lead to suicide (Watson, Clark, \& Carey 1988) 
In some problems, depression can make sufferers feel inferior continuously and directly affect them in their activities, either at work or hanging out with friends (Rosyanti, Hadi, \& Fitriwijayati 2018). Depression is the second problem causing the increase in the number of deaths in Indonesia and worldwide. It is undeniable that prolonged depression can lead to other mental illnesses. That is because sufferers take things that bother their minds lightly and make it seem like they do not have things that deviate from what they should be.

Individuals who are depressed have symptoms or things that make them behave differently than before. Those who have these symptoms choose to harbor them because they perceive their environment as not appreciating their actions and perceive it as deviations.

The Ministry of Health (in Pusat Data dan Informasi Kementerian Kesehatan RI or Center for Data and Information of the Indonesian Ministry of Health 2019) stated that Indonesia had experienced a significant increase in mental disorders affecting the population in Indonesia. Almost all age ranges experience this increase. This disease is complex for the sufferer to identify because it is related to taste and heart, challenging to pin down with logic.

In 2020, people with depressive disorders will continue to increase due to the Covid-19 pandemic that has attacked Indonesia since early March 2020. The pandemic has made people do all their activities from home or what we can call stay at home. People who are used to socializing with other people should stop doing this for a moment. That makes people more productive to surf on social media. It is undeniable that social media is a substitute for socialization in the real world that has stopped for a moment. However, over time, social media, which people used to use as needed and made users get new information, can make users feel the pressure that appears suddenly. That is called depression.

The results of research conducted online using Google Form media with questions containing measurements of the extent of the respondents' depression level, which shows the following data.

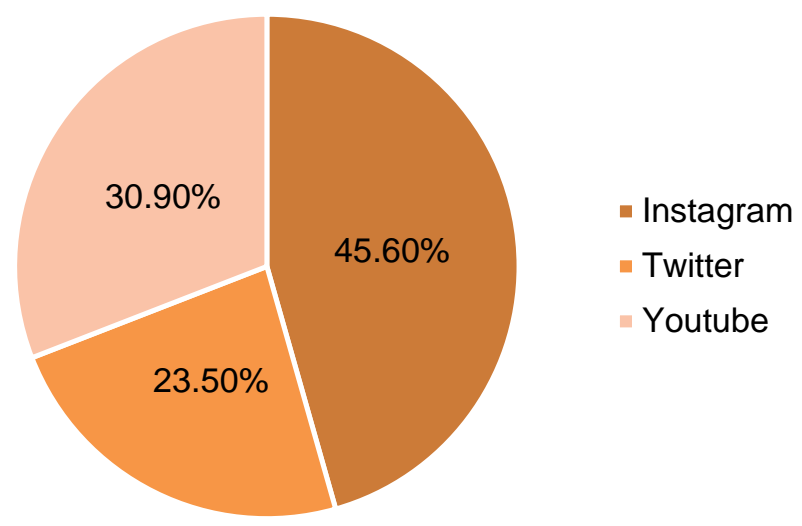

Diagram 1.

The social media platforms that respondents open frequently

Based on the 101 respondents who filled out the questionnaire, $79.2 \%$ of active social media users are women. Based on the study results, most respondents chose Instagram as the social media platform they visited frequently, then side by side with Youtube (30.9\%) and Twitter (23.5\%). Diagram 1 on the social media platforms that respondents open frequently shows that Instagram users reach $45.6 \%$, then Youtube follows with $30.9 \%$. That is because the platform provides content that makes its users seem to be satisfied when looking for information or seeing the lives of other people who are updated. 


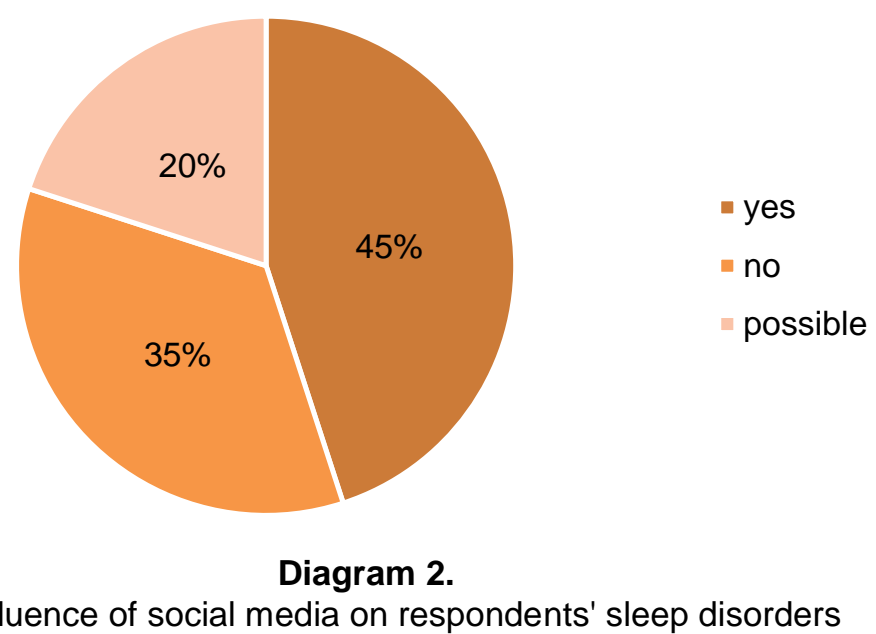

The influence of social media on respondents' sleep disorders

Activities that respondents always do at home make respondents have irregular sleeping hours, or what we can call insomnia. The respondents' sleep hours were disturbed due to activities that made them bored. Furthermore, diagram 2 shows that $45 \%$ of respondents who have this insomnia choose to use their sleep time by surfing social media. Respondents choose to surf on social media because they want to kill the feeling of boredom and sleepiness that never comes. Furthermore, this activity will continue to be repeated if the sufferer does not immediately limit it and starts to apply healthy sleep hours for the body. Although it can be challenging to apply a good sleep time but, applying this good sleep time can help a person to be able to recover from depression.

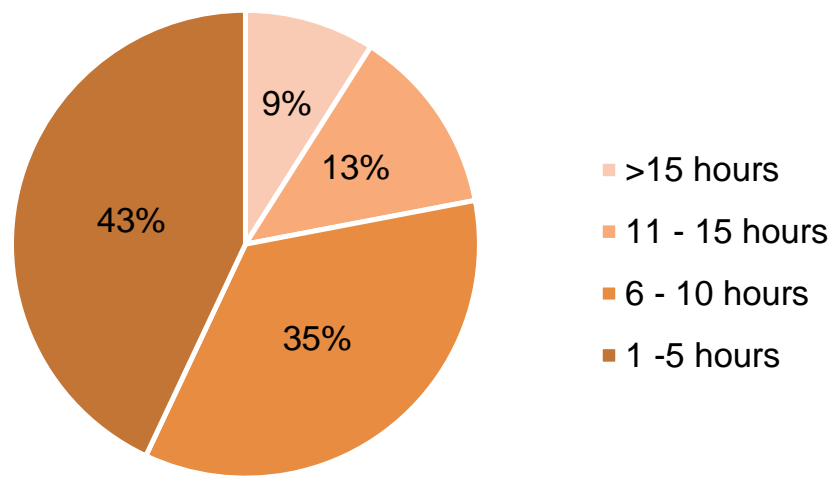

Diagram 3.

The length of time the respondent uses social media in a day

The time that respondents entirely spend at home every day makes respondents use social media applications much more often than when they worked or went to the school directly in the previous year. Initially, productive time became less productive because of surfing on social media. Diagram 3 about the length of time respondents use social media in a day shows that $9 \%$ of social media users spend more than 15 hours per day surfing social media. Besides, diagram 3 shows that the first majority of respondents use social media about one to five hours a day (43\%), and $35 \%$ of respondents use social media for six to ten hours a day. 
This activity is not good to often do because gadgets can make us healthy and waste our time. Eye health and skin will also decline due to the radiation emitted from our gadget screens, mainly if we use them in dark and low lightroom. Mental health will also be affected if we focus our activities on social media. Because this platform allows anyone to post what they want, and anyone can see it freely without filtering the information.

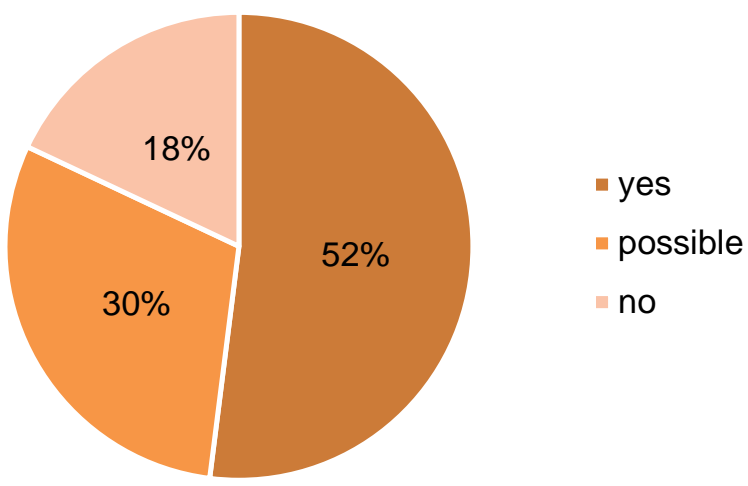

Diagram 4.

The influence of social media on changes in respondent mood

Diagram 4 shows that only a few respondents (18\%) do not experience mood changes, then $30 \%$ of respondents may experience mood changes due to social media. However, $52 \%$ of social media users experience significant mood swings when they view content. Sad or happy content from other people makes them feel that their feelings change rapidly with just one look at the content. That is very influential on a person's mind if done continuously. Also, seeing content that can cloud the mood can make someone feel wrong about going through their day.

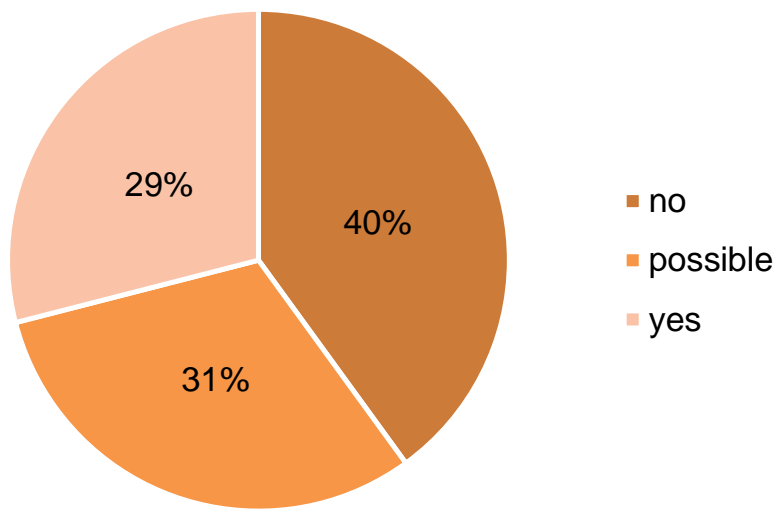

Diagram 5.

The effect of other people's posts on respondents' feelings of insecurity

Diagram 5 shows that $40 \%$ of respondents do not experience insecure feelings when viewing other people's posts, and $31 \%$ of respondents may experience feelings of insecurity when viewing other people's posts. However, diagram 4 also shows that $29 \%$ of respondents lack confidence after seeing other people's posts. Another name for this lack of confidence is insecurity. This lack of self- 
confidence comes from within the individual's heart and can mentally disturb the individual because he always sees other people better than him. This feeling can arise because they see the people they follow on social media have better lives and are luckier than them. Even though everyone has their advantages and also lives, that may have different paths for each person.

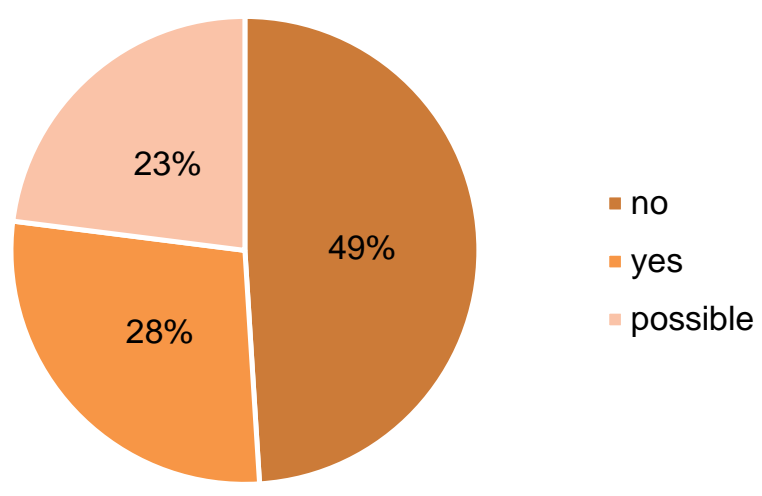

Diagram 6.

The influence of social media on the overthinking experienced by respondents

Diagram 6 has shown that $28 \%$ of respondents experienced overthinking or 'overthinking.' Furthermore, $23 \%$ of respondents still cannot focus on what they think in response to the content they see. Thinking about the future is okay, but if it is to damage oneself mentally, the individual should reduce and limit himself from viewing such content.

It is natural for individuals to think more about each other's future. However, if the overthinking is more than what it should be and the thought arises because they see posts about other people's successes, it will not be suitable. This thought can arise because individuals too often think that these individuals should be like them. Even though not everyone will have the same path in pursuing what is their success.

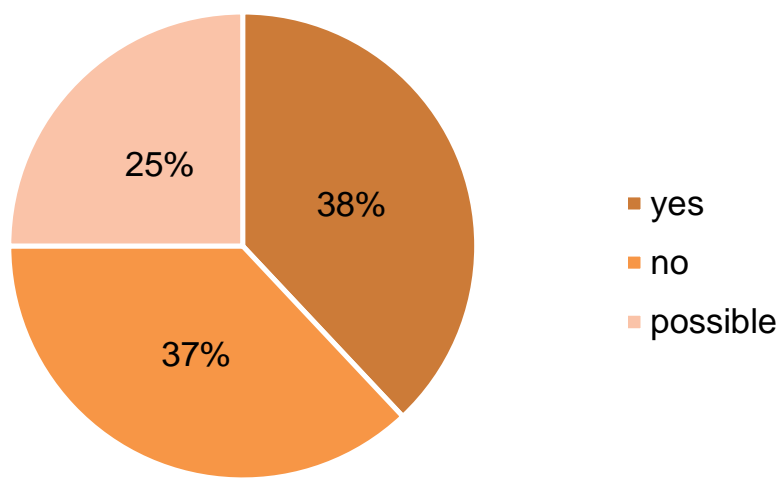

Diagram 7.

The influence of social media on respondents' feelings of loneliness

Diagram 7 shows that respondents' level of loneliness reached $38 \%$, then $37 \%$ of respondents did not feel lonely, and $25 \%$ of respondents may feel lonely. Respondents can feel lonely due to seeing how 
other people are seen as friends or family and post them on social media. Respondents feel lonely in their hearts after seeing the post, and it affects what activities they will do next.

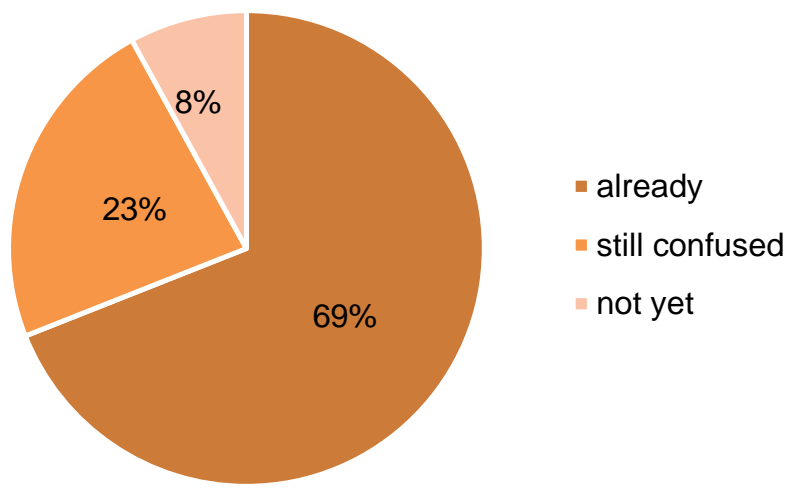

Diagram 8.

The influence of social media on respondents' happiness

Based on diagram 8,69\% of respondents are already happy with their lives, even though $23 \%$ feel confused about their happiness. However, $8 \%$ of respondents indicate that they are not happy with the life they are currently living. That is because the social media environment frees everyone to express themselves, so they become less happy with their current life. Besides, they also continue to compare other people's lives they think are happier than them. Furthermore, it creates a sense of depression to make themselves follow a lifestyle they consider happy.

\section{Analysis of the influence of social media use on mental health}

In this study, diagram 4 shows that $52 \%$ of respondents experience mood changes while using social media. Diagram 5 shows that $31 \%$ of respondents may share feelings of inferiority (insecure) when using social media. This feeling of uncertainty can occur due to changes in their mood due to excessive viewing of social media. Mahdia's research (2018) shows a direct relationship between influencer content on social media and the psychological well-being of late adolescents. This relationship indicates that if teens often watch content from influencers, their psychological wellbeing will also increase. According to Mahdia (2018), users who watch content from influencers need to filter the type of content that users see. That's because content on social media can affect psychological well-being, both positively and negatively. The positive impact of social media can provide education for the audience, but the negative effect of the excessive use of social media can trigger negative emotions.

Based on the study results, researchers found that depression occurs because of the level of someone's curiosity about other people. In this case, the researchers linked it to two theories closely related to depression caused by social media. Many people do not feel that they have a mental breakdown that leads to depression. Before reaching the point where a person experiences depression, there is a phase called Crab Mentality Syndrome. This syndrome is closely related to jealousy and wanting to criticize other people's behavior that they see or follow daily. In some cases, people who see someone else's success will feel pressured and want to bring that person down.

This syndrome is called crab syndrome because if there are several crabs in the bucket trying to get out of the bucket, then one of the crabs will step on the crab that is pushing it. The goal is so that the crab does not overtake him. That is what makes this syndrome called crab mental or Crab Mentality Syndrome (Monica 2020). People who experience this kind of mentality will feel that they are lacking 
and will always compare themselves with others who have been successful first. People who have a syndrome like this will be difficult to advise and invite to change their minds. That is because they will continue to be stuck thinking they should imitate the people they think are good. Besides, they believe that putting someone else down is the quickest choice for those who want to look better than that person.

Extensive social media and anyone can use it triggers jealousy and also wants to show something more than what makes them feel jealous (Armalita \& Helmi 2018). Indeed, these people will think that they are okay. However, deep down inside, they want to be like the person they see on social media. Even though it is only displayed virtually, jealousy will continue to grow. If the jealousy does not stop immediately, it will lead to significant depression. These theories strongly support that people can feel excessive envy because of what they see on social media.

The feeling that initially was just jealousy and wanting to be that person gradually became a feeling that led to depression, like overthinking, loneliness, and insecurity. These three sensations slowly eat away at a person and make them depressed because they cannot get what they want. Envy is indeed the root of all negative things that have lodged in a person. Plus, they see a lifestyle that is far different from their lifestyle, so that they make jealousy excited and want to be resolved immediately by being like that person. However, some people cannot do this because of their economic and social class constraints. Furthermore, this causes a person to lead himself into depression.

\section{Solutions to reduce depression due to excessive use of social media}

The solution that researchers can provide from this research is that individuals need to do several things to avoid or reduce their depression due to excessive use of social media. Doing activities that become a hobby can make a person forget about life's problems and envy others. That is because that actions will divert individuals' focus that the individual finds very enjoyable. Individuals like us will forget what makes us less grateful and jealous of others. If we do activities that make our hearts happy, or in other words, to be more productive even though we can do exercises at home that we like or new activities that if they have benefits for us. That way, we do not have time to think about other people they envy. Using less social media can make us much happier too. The use of social media as needed can help reduce jealousy and overthinking due to social media. Using social media only as necessary can help us control our souls do not feel more and more depressed. Limiting the use of social media is very necessary for individuals to mental health. Distracting it by playing games or listening to music can also slowly stop using social media.

Gratitude is the initial key to avoiding depressive symptoms. Even if they see things that seem much happier than themselves, they are more likely to be casual. It is because, in their hearts, they have received what they have today. Every time they see others' success, they will feel happy and think that they deserve it. When individuals feel gratitude in life, they will appreciate every second of their life more. They will continue to have a sense of being better from day to day, not to compare with other people, but as proof that they are grateful in life. According to Myers (2000) in Harpan (2015), everyone must be optimistic because this attitude can help individuals not be apathetic and depressed in a long way. Optimism is an attitude that expects something good to happen, and an optimistic mindset for a long time can provide benefits to reduce psychological problems in individuals. According to Harpan (2015), an optimistic attitude can make individuals more responsive to influences that are opposite to self and norms to strengthen themselves when acting. That can help individuals to be more grateful because they have their strengths.

According to Froh et al. (2010) in Harpan (2015), adolescents who involve themselves in helping others can improve psychological well-being. This psychological well-being makes adolescents more grateful, hopeful, optimistic, and happy. It can help teenagers to be less depressed, less jealous, less antisocial, and more diligent. In addition, religiosity also affects psychological well-being (Ismail and Desmukh 2013 in Harpan (2015); Park and Millora 2010 in Harpan (2015)). Religion has a vital role 
because it can bring individuals to be better (Diener 2000 in Harpan 2015; Myers 2000 in Harpan 2015). The values in religious teachings can overcome various psychological problems by forming positive emotions (Seligman \& Csikszentmihalyi 2000 in Harpan 2015). Becoming a better person by getting closer to God Almighty is the best solution. Having a strong bond with the Creator can make an individual will have a good personality. Furthermore, their seeking of identity by practicing their religion can reduce the risk of experiencing depression or other negative things.

The four solutions are solutions that teenagers and young adults can apply to not become boomerang due to the excessive use of social media in their lives. By doing these three things, the teenagers will live their real life in a much happier and more comfortable way. Overthinking, insecure and loneliness will slowly fade if individuals learn to accept life with gratitude. Besides, changing the direction of focus to a better place will help individuals to be able to live life well. Individuals who may experience mental problems will be able to avoid the symptoms of depression to feel happy with their life and no longer need to compare their life with other people, which can affect their life. The individual must have the confidence to start a better life. Furthermore, how they live their lives in the future is an obligation for these individuals to determine for themselves without involving the lives of other people who otherwise could not be good examples for themselves.

\section{Conclusion}

Teens tend to have unstable thoughts, making them prone to mental health problems, such as depression. Excessive use of social media also often has a negative mental impact on adolescents. This study's results also show that $43 \%$ of respondents use social media for one to five hours every day. However, the impact of social media appears in $45 \%$ of respondents who have difficulty sleeping (insomnia), and $38 \%$ of respondents who use social media also affect feelings of loneliness. In addition, $52 \%$ of respondents who frequently play social media also tend to experience mood swings due to negative emotions that arise when they watch content on their social media. To reduce the impact of excessive use of social media, users need to increase their optimism with gratitude or do other positive things to reduce the use of social media in everyday life. That will provide a balance in the lifestyle of adolescents so that they are not prone to depression due to overuse of social media.

\section{References}

Armalita R \& Helmi AF (2018) Iri di situs jejaring sosial: studi tentang teori deservingness. Jurnal Psikologi 45 (3):218-230. doi: 10.22146/jpsi.33313.

Davison GC \& Neale JM (2003) Abnormal Psychology with Cases (8th Ed.). New York: John Wiley $\&$ Sons.

Dine J (2010) A Global Crisis?, Companies, International Trade and Human Rights. Cambridge: Cambridge University Press. doi: 10.1017/cbo9780511660139.002.

Harpan A (2015) Peran religiusitas dan optimisme terhadap kesejahteraan psikologis pada remaja. EMPATHY: Jurnal Fakultas Psikologi 3 (1) : 1-17.

Husaini A (2018) Pengaruh Media Online terhadap Perilaku Kedisiplinan Remaja (Studi Desa Berembang Kecamatan Sekernan Kabupaten Muaro Jambi). Skripsi, Universitas Islam Negeri Sulthan Thaha Saifuddin, Jambi.

Kaplan AM \& Haenlein M (2010) Users of the world, unite! The challenges and opportunities of Social Media. Business Horizons 53 (1): 59-68. doi: 10.1016/j.bushor.2009.09.003.

Karmila S (2020) Hubungan Terapan Informasi Makanan pada Media Sosial Instagram dengan Perilaku Makan pada Mahasiswa di Universitas Sumatera Utara Tahun 2019. Thesis, Universitas Sumatera Utara, Medan. 
Mahdia A (2018) Pengaruh konten influencer di media sosial terhadap kesejahteraan psikologis remaja akhir. Jurnal Ilmiah Psikologi 11 (2):172-179.

Monica C (2020) Mengenal 'crab mentality', sindrom psikologis yang menghambat kesuksesan orang lain. [Diakses Desember 2020]. https://journal.sociolla.com/lifestyle/mengenal-crab-mentality.

Ninaprilia Z \& Rohmani CF (2015) Gangguan mood episode depresi sedang. Journal Medula Unila 4 (2):182-187.

Pratiwi N \& Nola P (2017) Pengaruh literasi digital terhadap psikologis anak dan remaja. SEMANTIK 6 (1):11-24.

Pusat Data dan Informasi Kementrian Kesehatan RI (2019) Situasi Kesehatan Jiwa di Indonesia. [Diakses Desember 2020]. https://pusdatin.kemkes.go.id/article/view/20031100001/situasikesehatan-jiwa-di-indonesia.html.

Putri WSR, Nunung N, \& Meilanny BS (2016) Pengaruh media sosial terhadap perilaku remaja. Prosiding Penelitian \& Pengabdian Kepada Masyarakat 3 (1):47-51.

Rosyanti L, Hadi I, \& Fitriwijayati (2018) Memahami gangguan depresi mayor (major depression disorder): Pendekatan psikoneuroimunologi; Kajian sitokin, trypthopan, HPA-Aksis. [Diakses Desember 2020]. https://www.researchgate.net/publication/335676275_EBOOK_MEMAHAMI_GANGGUAN_DEPRESI_MAYOR.

Sabbah H, Berbari R, Khamis R, Zorkot D, Sabbah S, Droubi N, \& Sabbah I (2019) The social media and technology addiction and its associated factors among university students in Lebanon using the media and technology usage and attitudes scale (MTUAS). Journal of Computer and Communications 07 (11):88-106. doi: 10.4236/jcc.2019.711007.

Setiawan D (2018) Dampak perkembangan teknologi informasi dan komunikasi terhadap budaya. SIMBOLIKA 4 (1):62-72.

Sugiyono (2016) Metode Penelitian Kuantitatif, Kualitatif, dan R\&D. Bandung: Alfabeta.

Watson D, Clark LA, \& Carey G (1988) Positive and negative affectivity and their relation to anxiety and depressive disorders. Journal of Abnormal Psychology 97 (3):346-353. doi: 10.1037/0021843X.97.3.346.

Yolanda R (2019) Fenomena Relasi Sosial di Era Digital Native (Studi Deskriptif tentang Alienasi pada Kalangan Mahasiswa di Universitas Sumatera Utara). Skripsi, Universitas Sumatera Utara, Medan. 